\title{
Penerapan Model Pembelajaran Kooperatif Make a Match Sebagai Upaya Meningkatkan Hasil Belajar Aqidah Akhlak Materi Asmaul Husna Kelas V
}

\author{
Mursyidawati \\ Madrasah Ibtidaiyah Hidayatullah Martapura, Kalimantan Selatan, Indonesia \\ email: mursyidawati@gmail.com
}

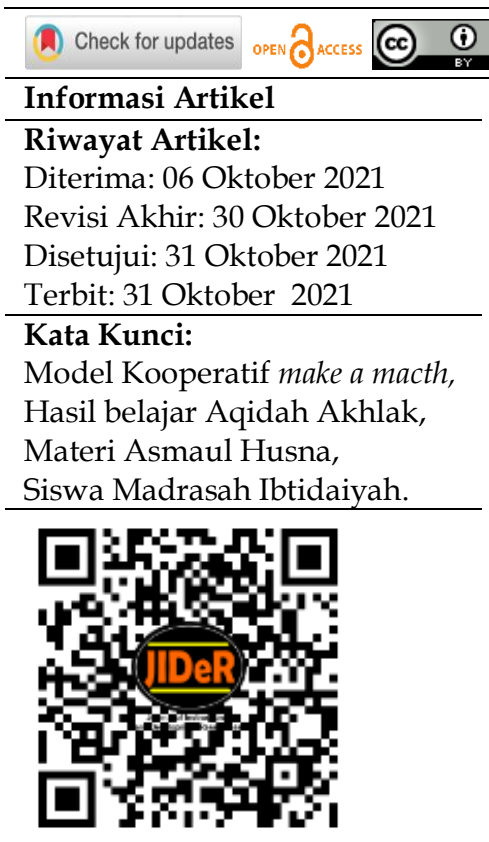

DOI: https://doi.org/10.53621/jider.v1i2.57

\begin{abstract}
ABSTRAK
Penelitian ini bertujuan bagaimana penerapan model kooperatif make a match untuk meningkatkan hasil belajar Akidah Akhlak materi Asmaul Husna siswa kelas V MIS Hidayatullah. Penelitian ini dirancang dengan Penelitian Tindakan Kelas (PTK) atau yang disebut classroom action research, prosedur pelaksanaan tindakan kelas dalam penelitian ini diatur dalam skenario model penelitian tindakan kelas dengan rancangan distrukturkan dalam dua siklus, dimana Siklus I merupakan prerekuiset dari siklus berikutnya. Setiap siklus terdiri dari 4 tahapan (langkah), yaitu Perencanaan, Pelaksanaan, Pengamatan dan Refleksi, dilaksanakan di Kelas 5A, berjumlah 16 orang. Jumlah laki-laki sebanyak 6 orang dan siswa perempuan berjumlah 10 orang. Adapun lokasi di MIS Hidayatullah Martapura Jl. Pangeran Hidayatullah No. 1A. Hasil penelitian Tindakan kelas yang sudah dilakukan bahwa Penerapan Model Pembelajaran Kooperatif Make A Match Materi Mengenal Allah swt Melalui Asmaul Husna, dapat meningkatkan Hasil Belajar Siswa Kelas 5A MI Hidayatullah Martapura Semester 1 Tahun Pelajaran 2021/2022 dengan tingkat ketuntasan pada siklus I sebanyak 62,5\% dan siklus II sebanyak $81,25 \%$. Adapun peningkatan ketuntasan dari siklus I dan Siklus II sebesar 18, $75 \%$. Peningkatan tersebut terjadi karena dalam metode make a match memiliki karakteristik seperti kerjasama, permainan, dan penghargaan (hadiah) sehingga siswa dapat bekerja sama dalam memecahkan masalah sertatercipta suasana belajar yang menyenangkan, asyik, dan aktif.
\end{abstract}

\section{PENDAHULUAN}

Pembelajaran sebagaimana dicantumkan dalam Undang-undang No. 20 Tahun 2003, adalah proses interaksi peserta didik dengan pendidik dan sumber belajar pada suatu lingkungan belajar. Definisi ini sejalan dengan yang dikemukakan oleh pakar pendidikan bahwa pengajaran/pembelajaran suatu proses yang kompleks, dimana di dalamnya terjadi interaksi antara mengajar dan belajar. Didalam proses ini kita akan dapat melihat berbagai aspek atau faktor, yakni guru, siswa, tujuan, metode, penilaian dan sebagainya (Wahyono et al., 2020).

Guru hendaknya mampu menghantarkan anak didiknya pada kemampuan yang diharapkan yaitu berfikir kritis, kreatif dan terbuka serta demokratis menerima orang lain dan sebagainya. Guru dan cara mengajarnya merupakan faktor yang penting. Sikap dan kepribadian guru, tinggi rendahnya pengetahuan yang dimiliki guru dan bagaimana cara guru mengajarkan pengetahuan tersebut kepada peserta didiknya serta alat-alat yang digunakan guru dalam proses belajar mengajar turut menentukan hasil belajar yang akan dicapai (Delila M, 2017).

Pembelajaran dengan tujuan akhir untuk mencapai hasil belajar yang dihasilkan siswa. Hasil belajar tersebut terdiri dari informasi verbal, keterampilan intelek, keterampilan motorik, sikap dan siasat kognitif. Dalam Kamus Besar Bahasa Indonesia hasil belajar diartikan sebagai hasil yang dicapai (dari telah dilakukan, dikerjakan dan sebagainya) hasil belajar adalah penguasaan pengetahuan atau keterampilan yang dikembangkan oleh mata pelajaran, lazimnya ditunjukkan dengan nilai tes atau angka yang diberikan oleh guru. Sehingga dapat dipahami bahwa hasil belajar adalah suatu perubahan yang terjadi pada siswa setelah melakukan proses 
pembelajaran yang diperoleh siswa yang berupa nilai dari mengerjakan tes. Hasil belajar itu meliputi semua aspek prilaku (aspek kognitif, efektif dan psikomotorik), hasil belajar itu sangat penting dalam proses pembelajaran, karena dengan adanya hasil belajar seorang guru dapat mengetahui sejauh mana siswa memahami materi yang telah disampaikan (Sugiarti \& Pribadi, 2013).

Mata pelajaran akidah akhlak adalah salah satu mata pelajaranyang mengajarkan tentang asas agama islam dan juga mengajarkan tentang perilaku, sehingga peserta didik dapat mengenal, memahami, menghayati dan mengimani Allah Swt dan dapat menerapkan dalam kehidupan sehari-hari. Mata pelajaran akidah akhlak merupakan satu mata pelajaran pendidikan agama islam yang merupakan peningkatan dari aqidah dan akhlak yang telah dipelajari oleh peserta didik

Dalam kegiatan proses belajar mengajar, siswa sering sekali mengalami masalah karena kurangnya motivasi belajar siswa. siswa kurang aktif, siswa tidak fokus dalam mengikuti pembelajaran, ketika dalam proses pembelajaran siswa cenderung asik ngobrol dengan teman sebangkunya hal tersebut otomatis membuat siswa tidak fokus dengan materi yang di sampaikan oleh guru, sehingga ketika guru memberikan pertanyaan siswa tidak bisa menjawab karena siswa tidak faham dengan materi yang di sampaikan oleh guru, hal tersebut berimbas pada rendahnya hasil belajar yang diperoleh oleh siswa. Bahwa hasil belajar Kelas V MIS Hidayatullah Martapura mata pelajaran Akidah Akhlak dapat dikatakan masih rendah yang terbukti dari rata-rata hasil belajar siswa masih dibawah Kriteria Ketuntasan Minimal (KKM). Masalah yang dihadapi kelas $\mathrm{V}$ dari hasil belajar yang rendah dikarenakan metode yang digunakan adalah metode ceramah yang belum maksimal.

Model pembelajaran (Saenab et al., 2017; Sai, 2017; Wijanarko, 2017; Safaruddin, et al., 2020) sebagai salah satu komponen yang utama harus dipenuhi dalam proses pembelajaran, sebagai upaya memperbaiki hasil belajar siswa sehingga dapat diupayakan secara maksimal dengan cara memilih model pembelajaran yang tepat untuk materi pelajaran terutama pada mata pelajaran Akidah Ahlak. Terdapat pula model-model pembelajaran pada masa Covid-19 di Indonesia saat ini (Hairiah, 2021).

Model pembelajaran make a match dikembangkan oleh Lorna Curran. Model pembelajaran make a match adalah pembelajran dimana siswa mencari pasangan sambil mempelajarai konsep atau topik tertentu dalam suasana yang menyenangkan. Setiap siswa mendapat sebuah kartu (soal atau jawaban) lalu secepatnya mencari pasangan yang sesuai dengan kartu yang di pegang. Suasana pembelajaran pada make a match akan riuh. Tetapi asik dan menyenangkan, strategi ini dapat di terapkan pada semua mata pelajaran dan lingkungan kelas.

Beberapa penelitian tentang efektifitas model kooperatif make a match pada materi gas ideal di SMA Negeri 2 Semarang (Astika, 2012), membantu guru dalam menciptakan suasana proses pembelajaran yang aktif dan menyenangkan dalam pembelajaran IPA di Sekolah Dasar (Wijanarko, 2017), demikian pula dengan hasil belajar siswa yang menggunakan model Picture and Picture dan Make a Match memiliki kemampuan yang seimbang (Prihatiningsih \& Setyanigtyas, 2018).

Dengan mempertimbangkan masalah yang terjadi di MIS Hidayatullah Martapura peneliti mencoba memperkenalkan model Pembelajaran kooperatif make a match, peneliti memilih menggunakan metode pembelajaran kooperatif make a match ini karena dalam metode ini ada unsur permainan dan metode ini menyenangkan (Wijanarko, 2017) sehingga siswa tidak mudah bosan dalam proses pembelajaran, metode make a match ini juga sebagai usaha untuk meningkatkan hasil belajar siswa. dengan demikian, pembelajaran akidah akhlak menjadi pembelajaran yang aktif, kreatif dan menyenangkan. Sehingga pada pembelajaranakidah akhlak digunakan model pembelajaran kooperatif make a match untuk meningkatkan hasil belajar siswa kelas V MIS Hidayatullah dengan materi Asmaul Husna. 
Pertanyaan kunci dalam penelitian ini adalah apakah melalui penerapan Model pembelajaran kooperatif Make A Match pada mata pelajaran akidah akhlak materi Asmaul Husna dapat meningkatkan hasil belajar siswa kelas V MIS Hidayatullah? Sedangkan tujuan dalam penelitian ini adalah bagaimana penerapan model kooperatif make a match untuk meningkatkan hasil belajar Akidah Akhlak materi Asmaul Husna siswa kelas V MIS Hidayatullah tahun ajaran 2021/2022. Dengan skema kerangka berpikir sebagai berikut:

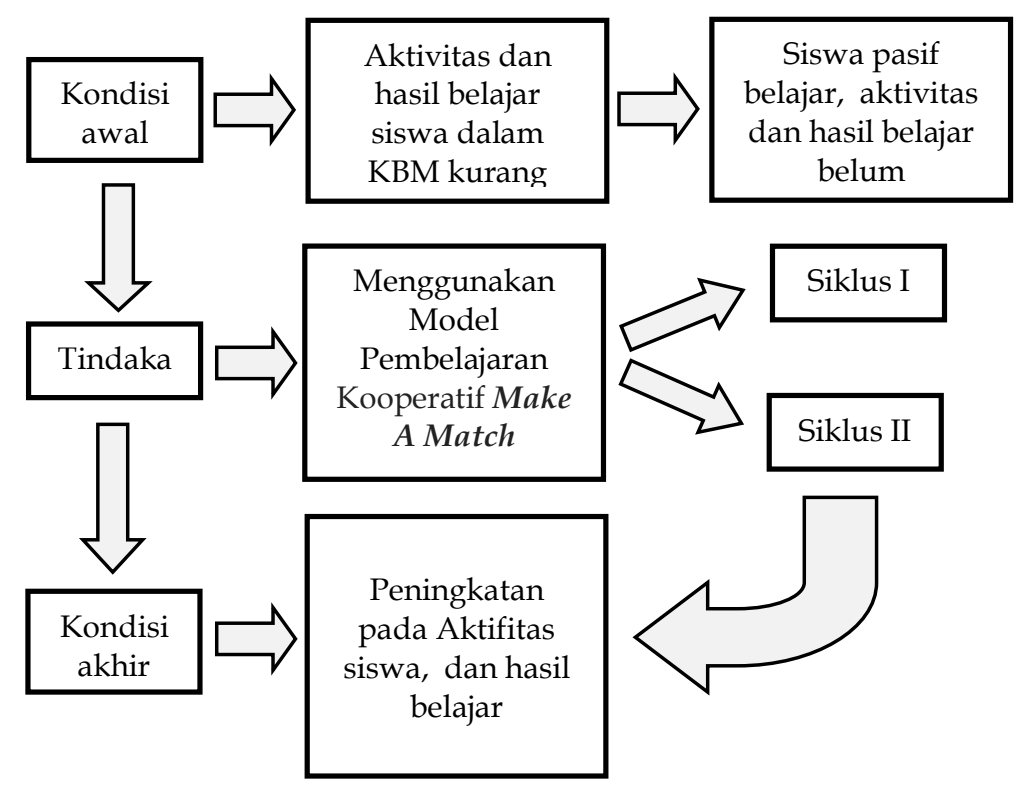

Gambar 1. Skema Kerangka Berfikir

\section{METODE PENELITIAN}

Penelitian ini dirancang sesuai dengan pola Penelitian Tindakan Kelas (PTK) atau yang disebut classroom action research. Penelitian tindakan kelas merupakan pencermatan terhadap kegiatan belajar berupa sebuah tindakan, yang secara sengaja dimunculkan dan berlangsung di dalam kelas secara bersama. (Arikunto, 2010). Penelitian Tindakan Kelas merupakan penelitian yang dilakukan oleh guru di dalam kelas melalui refleksi diri, dengan tujuan untuk mengembangkan keterampilan atau pendekatan baru, dan untuk memecahkan masalah serta memperbaiki kinerjanya sebagai guru sehingga hasil belajar siswa bisa ditingkatkan (Sugiono, 2016).

Penelitian ini dilaksanakan di Kelas 5, berjumlah 16 orang. Jumlah laki-laki sebanyak 6 orang dan siswa perempuan berjumlah 10 orang. Adapun lokasi di MIS Hidayatullah Martapura Jl. Pangeran Hidayatullah No. 1A.

Prosedur pelaksanaan tindakan kelas dalam penelitian ini diatur dalam skenario model penelitian tindakan kelas dengan rancangan distrukturkan dalam dua siklus, dimana Siklus I merupakan prerekuiset dari siklus berikutnya. Setiap siklus terdiri dari 4 tahapan (langkah), yaitu Perencanaan, Pelaksanaan, Pengamatan dan Refleksi.

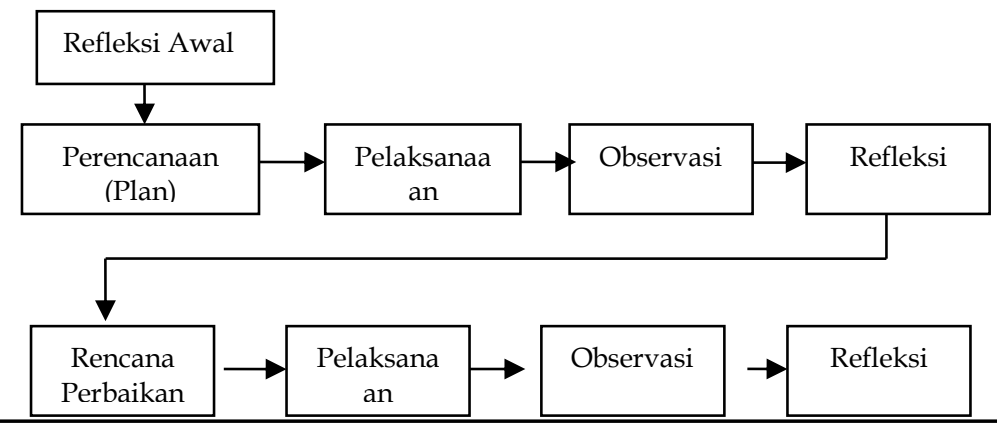


Gambar 2. Skema Penelitian

Prosedur pelaksanaan tindakan kelas dalam penelitian ini dilaksanakan sebanyak 2 kali siklus dengan 4 jam tatap muka (JTM) dan diatur dalam skenario dengan langkah-langkah sebagai berikut :

\section{Skenario Tindakan}

Prosedur pelaksanaan tindakan kelas dalam penelitian ini dilaksanakan sebanyak 2 kali siklus dengan 4 jam tatap muka (JTM) dan diatur dalam skenario dengan langkah-langkah pelaksanaan penelitian tindakan pada siklus I adalah sebagai berikut:

\section{Tahap Perencanaan}

Merencanakan suatu kegiatan merupakan aktivitas yang harus dilakukan setiap orang agar hasil yang dicapai sesuai dengan apa yang diharapkan. Pada tahap perencanaan peneliti melalukan beberapa tahap, yaitu : Mempelajari silabus Kelas V Hidayatullah, Merancang skenario pembelajaran yang dijabarkan dalam Rencana Pelaksanaan Pembelajaran (RPP). Menyiapkan alat dan media pembelajaran sesuai dengan rencana pembelajaran yang dibuat. Dan Menyusun instrumen penelitian berupa tes (tes hasil belajar).

\section{Tahap Pelaksanaan Tindakan}

Dalam pelaksanaan tindakan dilakukan kegiatan sebagai berikut: Melaksanakan kegiatan belajar mengajar, dalam kegiatan ini dilakukan dengan mengkaji konsep sesuai tuntutan kurikulum dengan penggunaan metode pembelajaran Kooperatif Make A Match. Dan Melaksanakan pos test siklus I.

Observasi, Pada tahap ini dilakukan observasi terhadap aktivitas siswa dalam proses belajar mengajar.

Refleksi, Berdasarkan hasil evaluasi belajar siswa dan evaluasi terhadap jurnal harian dengan menggunakan instrumen dan hasil tes, maka hal-hal ini digunakan sebagai pertimbangan untuk memasuki siklus ke II.

Analisis data diawali dengan kegiatan penskoran terhadap sejumlah pertanyaan atau soal yang diajukan. Selanjutnya skor yang diperoleh dianalisis dengan sistem penilaian agar diketahui tingkat pemahaman atau ketuntasan belajar siswa pada konsep yang dipelajari. Rumus yang digunakan adalah Depdiknas (2009) adalah:

$$
\mathrm{N}=\frac{\text { SkorPerolehan }}{\text { SkorMaksimal }} x 100
$$

\section{HASIL DAN PEMBAHASAN \\ Deskripsi Kondisi Awal}

Madrasah MI Hidayatullah memiliki 13 rombongan belajar, 1 ruangan kantor. Dari 13 rombongan belajar yang ada di sekolah ini, peneliti hanya mengambil 1 (satu) rombongan belajar yang dijadikan penelitian, yaitu Kelas 5a. Peneliti sengaja mengambil objek penelitian pada Kelas Va karena peneliti menilai dalam kegiatan belajar mengajar, sebagian besar siswanya kurang antusias mengikuti pelajaran. Gambaran lain tentang siswa Kelas Va yang menjadi objek penelitian tindakan kelas ini adalah: sebagai berikut:

Tabel 1. Data Nilai Hasil Belajar Kondisi Awal

\begin{tabular}{clccc}
\hline \multirow{2}{*}{ No } & & \multirow{2}{*}{ Nawa Siswa } & \multicolumn{3}{c}{ Nilai dan Keriteria } \\
\cline { 3 - 5 } & & Nilai & Tuntas & Tidak Tuntas \\
\hline 1 & Ahmad Fadillah & 70 & & $\sqrt{ }$ \\
2 & Ahmad Nabawi & 80 & $\sqrt{ }$ & \\
3 & M. Rizqi Ramadhan & 80 & $\sqrt{ }$ & \\
\hline
\end{tabular}


Penerapan Model Pembelajaran Kooperatif Make a Match Sebagai Upaya Meningkatkan Hasil Belajar Aqidah Akhlak Materi Asmaul Husna Kelas V

\begin{tabular}{|c|c|c|c|c|}
\hline 4 & Muhammad & 70 & & $\sqrt{ }$ \\
\hline 5 & Muhammad Nur Rafly & 80 & $\sqrt{ }$ & \\
\hline 6 & Nor Aini & 60 & & $\sqrt{ }$ \\
\hline 7 & Nur Fayza & 70 & & $\sqrt{ }$ \\
\hline 8 & Riski Amalia & 80 & $\sqrt{ }$ & \\
\hline 9 & Rizkia Halwa & 70 & & $\sqrt{ }$ \\
\hline 10 & Rodhiah & 80 & $\sqrt{ }$ & \\
\hline 11 & Selvina & 80 & $\sqrt{ }$ & \\
\hline 12 & Siti Halimatus Sa'diyah & 80 & $\sqrt{ }$ & \\
\hline 13 & Tiara Ayu Anindia Putri & 70 & & $\sqrt{ }$ \\
\hline 14 & Wardatul Fitria & 70 & & $\sqrt{ }$ \\
\hline 15 & Zahratul Ain & 70 & & $\sqrt{ }$ \\
\hline \multirow[t]{5}{*}{16} & Zupiru Camaliya & 60 & & $\sqrt{ }$ \\
\hline & Jumlah & 1170 & & \\
\hline & Rata-rata & 73,13 & $43,75 \%$ & $56,25 \%$ \\
\hline & Nilai Tertinggi & 80 & & \\
\hline & Nilai Terendah & 60 & & \\
\hline
\end{tabular}

Dari tabel di atas dapat divisualisasikan dalam bentuk grafik untuk skor masing-masing siswa:

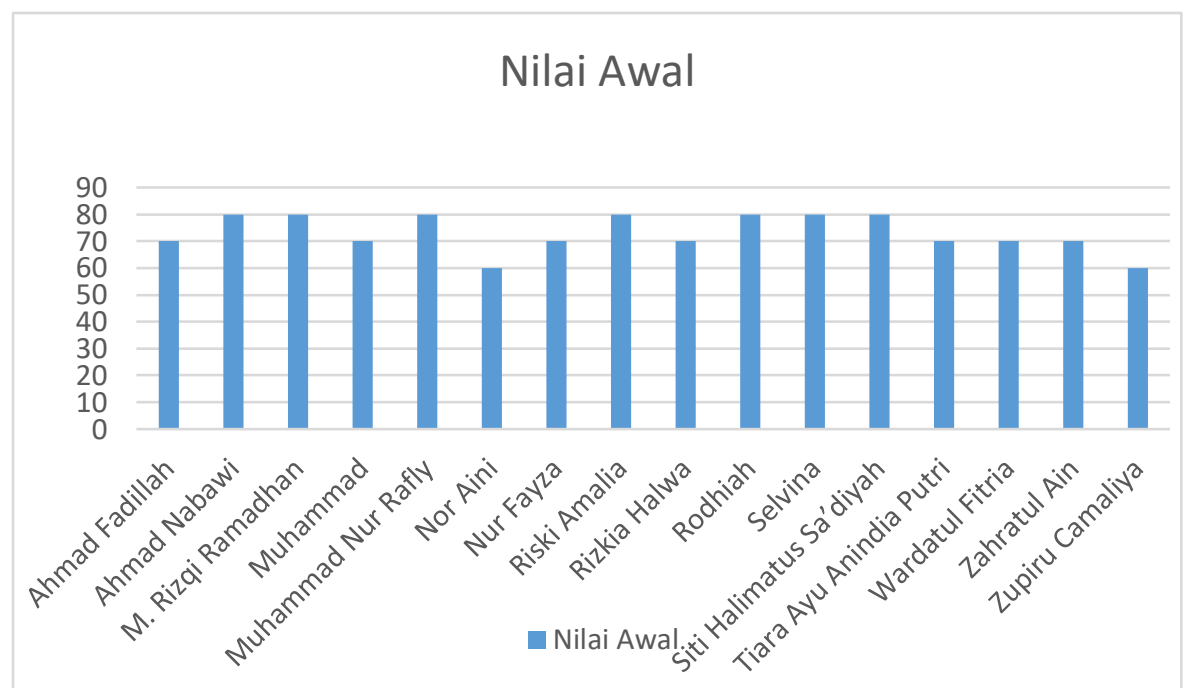

Gambar 3. Grafik Visualisasi Data Hasil Belajar Kondisi Awal Pembelajaran Siswa

Berdasarkan data diatas tercatat hanya 7 orang siswa Kelas V A yang mencapai KKM dalam belajar, yang artinya baru 43,75\% siswa yang mencapai KKM dan 9 orang siswa atau $56,25 \%$ dinyatakan belum mencapai nilai KKM.

\section{Diskripsi Data Hasil Penelitian}

Proses pembelajaran dalam penelitian ini dilaksanakan dalam 2 siklus. Tahap pertama dari penelitian ini yaitu tahap perencanaan, sebelum melakukan tahap perancanaanini, peneliti melakukan refleksi awal yang bertujuan untuk mengetahui kondisi kelas dan keadaan di kelas V A MI Hidayatullah. Adapun hasil refleksi awal diperoleh informasi bahwa jumlah siswa di kelas Va yaitu 33 siswa terdiri dari 15 siswa laki-laki dan 18 siswa perempuan. Namun pada situasi seperti saat ini, maka kelas VA dan juga kelas-kelas lainnya dibagi menjadi 2 shif. Dalam penelitian ini, peneliti cuma meneliti 1 shif yaitu pada shif 2 yang berjumlah 16 siswa. 
Sedangkan terkait pembelajaran Akidah Akhlak di MI Hidayatullah sudah berjalan dengan baik namun guru masih kurang dalam membuat variasi pembelajaran guru hanya menyampaikan materi secara verbalisme saja dan sangat jarang menggunakanMetode dalam proses pembelajaran.

Berdasarkan hasil data awal diketahui hasil belajar siswa yang belum mencapai KKM yaitu 9 siswa dengan presentase 56,25\% sedangkan hasil belajar siswa yang sudah mencapai KKM sebanyak 7 siswa dengan presentase $43,75 \%$ Rendahnya hasil belajar tersebut disebabkan siswa kurang aktif, siswa tidak fokus dalam mengikuti pembelajaran, ketika dalam proses pembelajaran siswa cenderung asik ngobrol dengan teman sebangkunya hal tersebut otomatis membuat siswa tidak fokus dengan materi yang di sampaikan oleh guru, sehingga ketika guru memberikan pertanyaan siswa tidak bisa menjawab karena siswa tidak faham dengan materi yang di sampaikan oleh guru, hal tersebut berimbas pada rendahnya hasil belajar yang diperoleh oleh siswa.

Penelitian ini dilaksanakan dalam 2 siklus, setiap pertemuan terdiri dari 2 jam pelajaran ( $2 \times 35$ menit) pada tiap kali pertemuan. Adapun uraian kegiatan disetiap siklus sebagai berikut:

\section{Siklus I}

\section{Persiapan Pembelajaran}

Sebagaimana prosedur penelitian tindakan kelas dengan menggunakan model make $A$ Match, maka persiapan yang dilakukan dalam pelaksanaan siklus I baik dalam pertemuan pertama maupun pertemuan ke dua adalah sebagai berikut:

a. Menyusun skenario pembelajaran pada Materi mengenal Allah melalui Asmaul Husna dengan menggunakan model pembelajaran Make A Macch

b. Menetapkan pelaksanaan tindakan kelas sebanyak 2 kali pertemuan, yaitu pada hari Kamis tanggal 12 Agustus 2021, jam pelajaran ke 1 - 2 pukul 08.30 - 09.40 (2 x 35 menit) untuk pertemuan pertama, dan hari Senin, 23 Agustus 2021 pukul 08.30 - 09. 40 untuk pertemuan ke dua.

c. Membuat Rencana Pelaksanaan Pembelajaran (RPP)

d. Membuat dan mempersiapkan Lembar Kerja Peserta Didik (LKPD) sesuai materi yang disampaikan

e. Mempersiapkan Materi pokok mengenal Allah melalui Asmaul Husna (Ar-Rozzaq, AlFattah, Asy-Syakur, Al Mughny)

\section{Pelaksanaan}

\section{a. Pertemuan Pertama (Kamis, 12 Agustus 2021)}

1) Kegiatan Awal (10 menit)

Guru memasuki ruang Kelas Va, serta mengucapkan salam dan siswa membalasnya. Setelah itu para siswa berdoa bersama-sama sebelum memulai pelajaran. Selanjutnya guru mengisi daftar hadir kelas/mengabsen siswa, guru memberikan motivasi kepada peserta didik, membagi siswa menjadi 4 kelompok, guru menyampaikan tujuan pebelajaran dengan menggunakan model pembelajaran make A Match agar siswa bisa memahami proses pembelajaran yang akan dilaksanakan lalu guru melakukan apersepsi tentang materi pelajaran yang akan disampaikan

2) Kegiatan Inti (40 menit)

Guru memulai pelajaran dengan menjelaskan materi Asmaul Husna Ar Razzaq, Al Fattah, Asyakur, Al Mughny). Siswa mendengarkan kemudian siswa dibimbing untuk menanyakan terkait dengan materi yang telah dijelaskan guru. Adapun langkah-langkah dari model pembelajaran Make A Match ini adalah sebagai berikut: a). membentuk kelompok yang anggotanya sebanyak 4 orang secara heterogen (campuran menurut prestasi, jenis kelamin, suku, dan lain-lain). b). guru membagi kartu terkait dengan materi. c). siswa mendapat satu buah kartu 
dan memikirkan jawaban atau soal dari kartu yang dipegang d). siswa mendiskusikan pada kelompok tentang soal atau jawaban dari kartu. e). siswa mencari pasangan yang mempunyai kartu yang cocok dengan kartunya f) siswa dapat mencocokkan kartunya akan diberi poin g) guru beserta siswa mengkonfirmasi hasil yang telah dikerjakan h) Siswa yang menemukan pasangannya mempersentasikan hasil pekerjaannya di depan kelas, siswa lain menanggapi i) guru memberikan penguatan terkait dengan materi

3) Penutup (20 menit)

Guru melakukan evaluasi dengan memberikan soal yang harus dijawab oleh siswa, Guru bersama-sama siswa membuat kesimpulan hasil pelajaran berkaitan dengan Materi Asmaul Husna (ar Rozaq, al Fattah, Asy Syakur, Al Mughny) dan memberikan umpan balik terhadap proses dan hasil pembelajaran. Guru memberitahukan kepada siswa mengenai materi pada pertemuan berikutnya dan mengakhiri pembelajaran dengan mengucap Hamdalah dan salam.

b. Pertemuan Kedua ( Senin, 23 Agustus 2021)

1) Kegiatan Awal (10 menit)

Guru memasuki ruang Kelas Va, serta mengucapkan salam dan siswa membalasnya. Setelah itu mengajak para siswa berdoa bersama-sama sebelum memulai pelajaran. Selanjutnya guru menanyakan keadaan siswa dan mengisi daftar hadir kelas/mengabsen siswa, guru memberikan motivasi kepada peserta didik, guru menyampaikan tujuan pebelajaran, agar siswa bisa memahami proses pembelajaran yang akan dilaksanakan lalu guru melakukan apersepsi atau menggali informasi dengan bertanya kepada siswa tentang materi pelajaran yang telah disampaikan minggu lalu.

2) Kegiatan Inti (40 menit)

Guru memulai pelajaran dengan menjelaskan materi Asmaul Husna Ar Razzaq, Al Fattah, Asyakur, Al Mughny). Siswa mendengarkan kemudian siswa dibimbing untuk menanyakan terkait dengan materi yang telah dijelaskan guru. Adapun langkah-langkah dari model pembelajaran Make A Match ini adalah sebagai berikut: a). guru membagi kelompok menjadi 2 kelompok b). guru membagi kartu terkait dengan materi. c). siswa mendapat satu buah kartu dan memikirkan jawaban atau soal dari kartu yang dipegang d). siswa mendiskusikan pada kelompok tentang soal atau jawaban dari kartu. e). siswa mencari pasangan yang mempunyai kartu yang cocok dengan kartunya f) siswa dapat mencocokkan kartunya akan diberi poin g) guru beserta siswa mengkonfirmasi hasil yang telah dikerjakan h) Siswa yang menemukan pasangannya mempersentasikan hasil pekerjaannya di depan kelas, siswa lain menanggapi i) guru memberikan penguatan terkait dengan materi yang telah dijelaskan

3) Penutup (20 menit)

Guru melakukan evaluasi dengan memberikan soal yang harus dijawab oleh siswa, Guru bersama-sama siswa membuat kesimpulan hasil pelajaran berkaitan dengan Materi Asmaul Husna (ar Rozaq, al Fattah, Asy Syakur, Al Mughny) dan memberikan penekanan kepada peserta didik agar senantiasa membiasakan diri meneladani sifat Allah ar Rozaq, al Fattah, Asy Syakur, Al Mughny dan mengakhiri pembelajaran dengan mengucap Hamdalah dan salam

\section{Hasil Tindakan Kelas Siklus I}

Data di bawah ini adalah nilai hasil belajar (post test) siswa yang dilakukan dengan menggunakan model pembelajaran Make A Match yang dilakukan pada siswa Kelas V A MI Hidayatullah Martapura. Kegiatan ini dilaksanakan pada hari Kamis , 12 Agustus 2021. Data hasil belajar siswa ini dapat dilihat pada tabel berikut:

Tabel 2. Data Nilai Hasil Belajar (Post test) siklus I

\begin{tabular}{llrrr}
\hline \multirow{2}{*}{ No } & \multirow{2}{*}{ Nawa Siswa } & \multicolumn{3}{c}{ Nilai dan Keriteria } \\
\cline { 3 - 5 } & & Nilai & Tuntas & Tidak Tuntas \\
\hline 1 & Ahmad Fadillah & 70 & & $\sqrt{ }$ \\
2 & Ahmad Nabawi & 80 & $\sqrt{ }$ & \\
\hline
\end{tabular}


Penerapan Model Pembelajaran Kooperatif Make a Match Sebagai Upaya Meningkatkan Hasil Belajar Aqidah Akhlak Materi Asmaul Husna Kelas V

\begin{tabular}{|c|c|c|c|c|}
\hline 3 & M. Rizqi Ramadhan & 80 & $\sqrt{ }$ & \multirow[b]{2}{*}{$\sqrt{ }$} \\
\hline 4 & Muhammad & 70 & & \\
\hline 5 & Muhammad Nur Rafly & 90 & $\sqrt{ }$ & \\
\hline 6 & Nor Aini & 60 & & 1 \\
\hline 7 & Nur Fayza & 70 & & 1 \\
\hline 8 & Riski Amalia & 80 & \multirow[t]{2}{*}{$\sqrt{ }$} & \\
\hline 9 & Rizkia Halwa & 70 & & \\
\hline 10 & Rodhiah & 80 & $\sqrt{ }$ & \\
\hline 11 & Selvina & 90 & $\sqrt{ }$ & \\
\hline 12 & Siti Halimatus Sa'diyah & 80 & $\sqrt{ }$ & \\
\hline 13 & Tiara Ayu Anindia Putri & 80 & $\sqrt{ }$ & \\
\hline 14 & Wardatul Fitria & 80 & $\sqrt{ }$ & \\
\hline 15 & Zahratul Ain & 80 & $\sqrt{ }$ & \\
\hline \multirow[t]{5}{*}{16} & Zupiru Camaliya & 70 & & 1 \\
\hline & Jumlah & 1230 & $62,5 \%$ & $37,5 \%$ \\
\hline & Rata-rata & 76,88 & & \\
\hline & Nilai Tertinggi & 90 & & \\
\hline & Nilai Terendah & 60 & & \\
\hline
\end{tabular}

Deskripsi Hasil Evaluasi Data Hasil Aspek Kognitif (Nilai Tes) dari tabel diatas dapat disimpulkan bahwa : yang memperoleh nilai $<75$ ada 6 orang, dengan rincian:

a. Yang memperoleh nilai 60: 1 orang

b. Yang memperoleh nilai 70: 5 orang

c. Yang memperoleh nilai $\geq 70$ : 10 orang

Penelitian hasil belajar siswa dapat dilihat berdasarkan siklus 1 pada tabel dibawah ini:

Tabel 3. Rata-rata nilai awal dan nilai siklus 1

\begin{tabular}{clcc}
\hline \multirow{2}{*}{ No } & \multirow{2}{*}{ Komponen Analisis } & \multicolumn{2}{c}{ Nilai rata-rata } \\
\cline { 3 - 4 } & & Nilai Awal & Siklus 1 \\
\hline 1. & Jumlah & 1170 & 1230 \\
2. & Rata-Rata & 73,13 & 76,88 \\
3. & Nilai Tertinggi & 80 & 90 \\
4. & Nilai Terendah & 60 & 60 \\
5. & Jumlah Tuntas & 7 & 10 \\
6. & Jumlah Tidak Tuntas & 9 & 6 \\
7. & Tingkat Ketuntasan & $43,75 \%$ & $62,5 \%$ \\
\hline
\end{tabular}

Berdasarkan data dari tabel di atas, selanjutnya dapat divisualisasikan dalam bentuk grafik untuk perolehan nilai masing-masing siswa: 


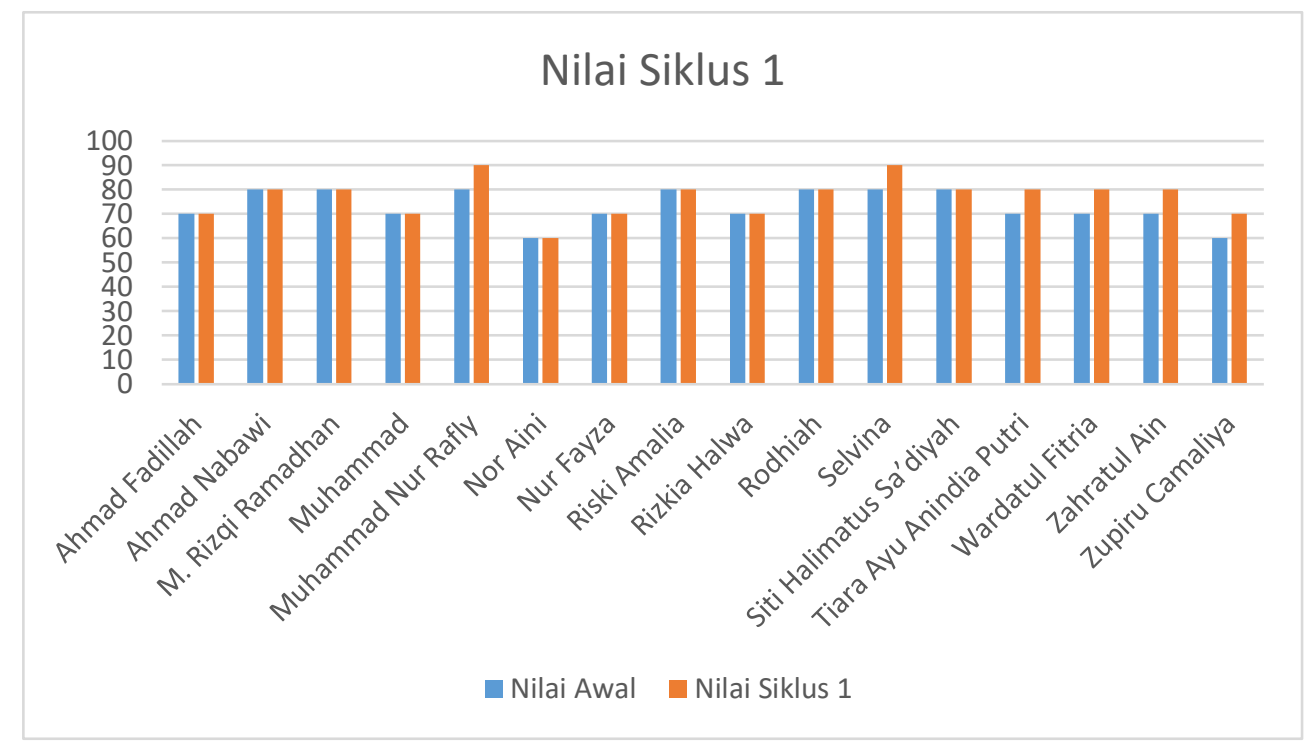

Gambar 4. Grafik Data Nilai Hasil Belajar (Post test) siklus I.

Dari tabel dan grafik di atas tentang hasil belajar siswa dengan menggunakan model pembelajaran make A Match pada siklus I diketahui rata-rata nilai pada post test adalah 76,88 dengan ketuntasan klasikal 62,5\%

\section{Refleksi}

Berdasarkan data pada tabel dan grafik di atas dapat dikemukakan bahwa kegiatan pembelajaran Materi mengenal Allah melalui Asmaul Husna dengan menggunakan model pembelajaran Make A Match pada Siswa Kelas Va MI Hidayatullah belum mampu meningkatkan hasil belajar secara optimal. Diantara penyebabnya adalah masih ada sebagian anak yang bingung saat mencari pasangan. Selain itu sebagian siswa asyik ngobrol atau berbicara dengan teman disampingnya, sehingga siswa tidak begitu menyimak penjelasan yang disampaikan oleh guru. Karena itu peneliti akan melanjutkan pembelajaran pada siklus II.

\section{Siklus II}

\section{Persiapan Pembelajaran}

Berdasarkan hasil pelaksanaan penelitian tindakan kelas siklus I, sebagaimana prosedur penelitian tindakan kelas untuk mrnggunakan model pembelajara Make A Macth, maka persiapan yang dilakukan dalam pelaksanaan siklus II tidak berbeda jauh dengan persiapan pembelajaran pada siklus I, yaitu sebagai berikut :

a. Menyusun skenario pembelajaran pada Materi mengenal Allah melalui Asmaul Husna dengan menggunakan model pembelajaran Make A Macth

b. Mempersiapkan Materi mengenal Allah melalui Asmaul Husna Ar-Rozaq, Al Fattah, asySyakur, al-Mughny

c. Melaksanaan tindakan kelas yang ke dua, yaitu pada hari Senin, 23 Agustus 2021 pukul 08.30 - 09. 40 wita ( $2 \times 35$ menit)

d. Membuat dan mempersiapkan Lembar Kerja Peserta Didik (LKPD) sesuai materi yang disampaikan

\section{Pelaksanaan}

a. Pertemuan Pertama (Kamis, 12 Agustus 2021)

1. Kegiatan Awal (10 menit)

Guru memasuki ruang Kelas Va, serta mengucapkan salam dan siswa membalasnya. Setelah itu para siswa berdoa bersama-sama sebelum memulai pelajaran. Selanjutnya guru mengisi daftar hadir kelas/mengabsen siswa, guru memberikan motivasi kepada peserta didik, 
membagi siswa menjadi 4 kelompok, guru menyampaikan tujuan pebelajaran dengan menggunakan model pembelajaran make A Match agar siswa bisa memahami proses pembelajaran yang akan dilaksanakan lalu guru melakukan apersepsi tentang materi pelajaran yang akan disampaikan

2. Kegiatan Inti (40 menit)

Guru memulai pelajaran dengan menjelaskan materi Asmaul Husna Ar Razzaq, Al Fattah, Asyakur, Al Mughny). Siswa mendengarkan kemudian siswa dibimbing untuk menanyakan terkait dengan materi yang telah dijelaskan guru. Adapun langkah-langkah dari model pembelajaran Make A Match ini adalah sebagai berikut: a). membentuk kelompok yang anggotanya sebanyak 4 orang secara heterogen (campuran menurut prestasi, jenis kelamin, suku, dan lain-lain). b). guru membagi kartu terkait dengan materi. c). siswa mendapat satu buah kartu dan memikirkan jawaban atau soal dari kartu yang dipegang d). siswa mendiskusikan pada kelompok tentang soal atau jawaban dari kartu. e). siswa mencari pasangan yang mempunyai kartu yang cocok dengan kartunya f) siswa dapat mencocokkan kartunya akan diberi poin g) guru beserta siswa mengkonfirmasi hasil yang telah dikerjakan h) Siswa yang menemukan pasangannya mempersentasikan hasil pekerjaannya di depan kelas, siswa lain menanggapi i) guru memberikan penguatan terkait dengan materi

3. Penutup (20 menit)

Guru melakukan evaluasi dengan memberikan soal yang harus dijawab oleh siswa, Guru bersama-sama siswa membuat kesimpulan hasil pelajaran berkaitan dengan Materi Asmaul Husna (ar Rozaq, al Fattah, Asy Syakur, Al Mughny) dan memberikan umpan balik terhadap proses dan hasil pembelajaran. Guru memberitahukan kepada siswa mengenai materi pada pertemuan berikutnya dan mengakhiri pembelajaran dengan mengucap Hamdalah dan salam.

\section{b. Pertemuan Kedua ( Senin, 23 Agustus 2021)}

1. Kegiatan Awal (10 menit)

Guru memasuki ruang Kelas Va, serta mengucapkan salam dan siswa membalasnya. Setelah itu mengajak para siswa berdoa bersama-sama sebelum memulai pelajaran. Selanjutnya guru menanyakan keadaan siswa dan mengisi daftar hadir kelas/mengabsen siswa, guru memberikan motivasi kepada peserta didik, guru menyampaikan tujuan pebelajaran, agar siswa bisa memahami proses pembelajaran yang akan dilaksanakan lalu guru melakukan apersepsi atau menggali informasi dengan bertanya kepada siswa tentang materi pelajaran yang telah disampaikan minggu lalu.

2. Kegiatan Inti (40 menit)

Guru memulai pelajaran dengan menjelaskan materi Asmaul Husna Ar Razzaq, Al Fattah, Asyakur, Al Mughny). Siswa mendengarkan kemudian siswa dibimbing untuk menanyakan terkait dengan materi yang telah dijelaskan guru. Adapun langkah-langkah dari model pembelajaran Make A Match ini adalah sebagai berikut: a). guru membagi kelompok menjadi 2 kelompok b). guru membagi kartu terkait dengan materi. c). siswa mendapat satu buah kartu dan memikirkan jawaban atau soal dari kartu yang dipegang d). siswa mendiskusikan pada kelompok tentang soal atau jawaban dari kartu. e). siswa mencari pasangan yang mempunyai kartu yang cocok dengan kartunya f) siswa dapat mencocokkan kartunya akan diberi poin g) guru beserta siswa mengkonfirmasi hasil yang telah dikerjakan h) Siswa yang menemukan pasangannya mempersentasikan hasil pekerjaannya di depan kelas, siswa lain menanggapi i) guru memberikan penguatan terkait dengan materi yang telah dijelaskan

3. Penutup (20 menit)

Guru melakukan evaluasi dengan memberikan soal yang harus dijawab oleh siswa, Guru bersama-sama siswa membuat kesimpulan hasil pelajaran berkaitan dengan Materi Asmaul Husna (ar Rozaq, al Fattah, Asy Syakur, Al Mughny) dan memberikan penekanan kepada peserta didik agar senantiasa membiasakan diri meneladani sifat Allah ar Rozaq, al Fattah, Asy Syakur, Al Mughny dan mengakhiri pembelajaran dengan mengucap Hamdalah dan salam 
Penerapan Model Pembelajaran Kooperatif Make a Match Sebagai Upaya Meningkatkan Hasil Belajar Aqidah Akhlak Materi Asmaul Husna Kelas V

\section{Hasil Tindakan Kelas Siklus II}

Hasil belajar yang telah dicapai oleh siswa Kelas Va setelah menggunakan model pembelajaran Make A Match pada siklus II menunjukkan keberhasilan yang sangat memuaskan. Ini bisa dilihat pada tabel berikut:

Tabel 4. Data Nilai Hasil Belajar (Post test) siklus II

\begin{tabular}{|c|c|c|c|c|}
\hline \multirow[t]{2}{*}{ No } & \multirow[t]{2}{*}{ Nawa Siswa } & \multicolumn{3}{|c|}{ Nilai dan Keriteria } \\
\hline & & Nilai & Tuntas & Tidak Tuntas \\
\hline 1 & Ahmad Fadillah & 63 & & $\sqrt{ }$ \\
\hline 2 & Ahmad Nabawi & 100 & $\sqrt{ }$ & \\
\hline 3 & M. Rizqi Ramadhan & 100 & $\sqrt{ }$ & \\
\hline 4 & Muhammad & 75 & $\sqrt{ }$ & \\
\hline 5 & Muhammad Nur Rafly & 100 & $\sqrt{ }$ & \\
\hline 6 & Nor Aini & 63 & & $\sqrt{ }$ \\
\hline 7 & Nur Fayza & 88 & $\sqrt{ }$ & \\
\hline 8 & Riski Amalia & 88 & $\sqrt{ }$ & \\
\hline 9 & Rizkia Halwa & 75 & $\sqrt{ }$ & \\
\hline 10 & Rodhiah & 88 & $\sqrt{ }$ & \\
\hline 11 & Selvina & 88 & $\sqrt{ }$ & \\
\hline 12 & Siti Halimatus Sa'diyah & 100 & $\sqrt{ }$ & \\
\hline 13 & Tiara Ayu Anindia Putri & 75 & $\sqrt{ }$ & \\
\hline 14 & Wardatul Fitria & 75 & $\sqrt{ }$ & \\
\hline 15 & Zahratul Ain & 88 & $\sqrt{ }$ & \\
\hline \multirow[t]{5}{*}{16} & Zupiru Camaliya & 63 & & $\sqrt{ }$ \\
\hline & Jumlah & 1329 & 81,25 & 18,75 \\
\hline & Rata-rata & 83,06 & & \\
\hline & Nilai Tertinggi & 100 & & \\
\hline & Nilai Terendah & 63 & & \\
\hline
\end{tabular}

Deskripsi Hasil Evaluasi Data Hasil Aspek Kognitif (Nilai Tes) dari tabel diatas dapat disimpulkan bahwa : yang memperoleh nilai < 75 ada 3 orang, dengan rincian:

a) Yang memperoleh nilai $63: 3$ orang

b) Yang memperoleh nilai $75: 4$ orang

c) Yang memperoleh nilai $\geq 75: 9$ orang

Penelitian hasil belajar siswa dapat dilihat berdasarkan siklus 2, dengan melihat tabel dibawah ini:

Tabel 5. rata-rata nilai awal dan nilai siklus 2

\begin{tabular}{llccc}
\hline & & \multicolumn{3}{c}{ Nilai rata-rata } \\
\cline { 3 - 5 } No & Komponen Analisis & Nilai Awal & Siklus 1 & Siklus 2 \\
\hline 1. & Jumlah & 1170 & 1230 & 1329 \\
2. & Rata-Rata & 73,13 & 76,88 & 83,06 \\
3. & Nilai Tertinggi & 80 & 90 & 100 \\
4. & Nilai Terendah & 60 & 60 & 63 \\
5. & Jumlah Tuntas & 7 & 10 & 13 \\
6. & Jumlah Tidak Tuntas & 9 & 6 & 3 \\
7. & Tingkat Ketuntasan & $43,75 \%$ & $62,5 \%$ & 81,25 \\
\hline
\end{tabular}


Penerapan Model Pembelajaran Kooperatif Make a Match Sebagai Upaya Meningkatkan Hasil Belajar Aqidah Akhlak Materi Asmaul Husna Kelas V

Berdasarkan data dari tabel di atas, selanjutnya dapat divisualisasikan dalam bentuk grafik untuk perolehan nilai masing-masing siswa:

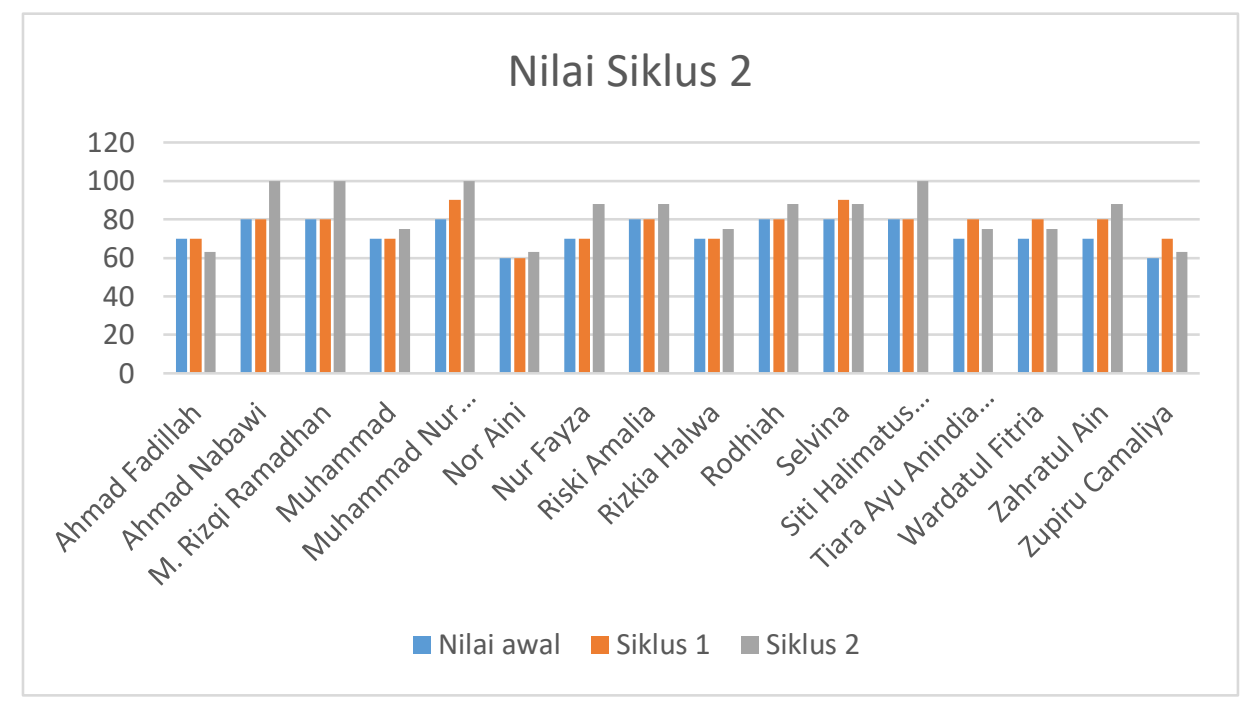

Gambar 5: Visualisasi Nilai Hasil Belajar (Post test) siklus II

\section{Refleksi}

Dari 16 siswa yang ada di Kelas $\mathrm{V}$ a sebanyak 13 siswa atau $81,25 \%$ berhasil mencapai nilai KKM dan hanya 3 orang atau 18,75 yang tidak mencapai nilai KKM. Melihat hasil yang diperoleh dalam pelaksanaan penelitian pada mata pelajaran Akidah Akhlak mengenai Materi Asmaul Husna dengan menggunakan model pembelajaran Make A Match pada siswa Kelas V a MI Hidayatullah, yang dilakukan sebanyak 2 siklus menunjukkan perubahan. Model pembelajaran ini sangat disukai oleh siswa.

Dari hasil belajar siswa pada siklus I ketercapaian hasil belajar siswa sudah mencapai hasil ketuntasan, namun masih ada beberapa siswa yang belum mencapai ketuntasan meskipun sudah digunakan model pembelajaran Make A Match. Ketidaktuntasan disebabkan oleh beberapa kendala yang terjadi pada saat pembelajaran berlangsung, antara lain a. Siswa merasa belum memahami materi yang dijelaskan oleh guru, karena guru tidak menjelaskan secara jelas materi karena guru menjelaskan secara singkat atau ringkas saja, dan siswa berusaha memahami sendiri materi, b. Guru memberikan kesempatan pada siswa untuk belajar aktif, tetapi siswa masih belum terbiasa dengan model pembelajaran yang diinginkan guru, dan c. Guru belum mampu menggunakan waktu secara efektif dan efisien, sehingga mengganggu jam pelajaran yang lain. Walaupun guru harus menerapkan beberapa model pembelajaran yang menunjang atau memberi pengaruh pada hasil belajar (Salehudin, 2020).

Tindakan pada siklus I ini dilaksanakan sesuai dengan langkah-langkah penggunaan model pembelajaran Make A Match), namun dalam pelaksanaannya masih banyak penggunaan langkah yang kurang memuaskan karena model pertama kali diterapkan sehingga masih butuh penyesuaian dan penyempurnaan. Pada siklus I, dari 16 siswa yang ada di Kelas 5A sebanyak 10 siswa atau $62,5 \%$ berhasil mencapai nilai KKM dan hanya 6 orang atau 37,5\% yang tidak mencapai nilai KKM.

Selanjutnya pada siklus II dari 16 siswa yang ada di Kelas 5 A sebanyak 13 siswa atau $81,25 \%$ berhasil mencapai nilai KKM dan hanya 3 orang atau $18,75 \%$ yang tidak mencapai nilai KKM. Hasil analisa data ini menunjukkan bahwa tindakan yang diberikan berupa penerapan model pembelajaran Make A Match untuk meningkatkan hasil belajar siswa pada siklus II dapat dikatakan berhasil (Sai, 2017). 
Penerapan Model Pembelajaran Kooperatif Make a Match Sebagai Upaya Meningkatkan Hasil Belajar Aqidah Akhlak Materi Asmaul Husna Kelas V

Sebagai gambaran yang jelas akan adanya peningkatan nilai hasil belajar siswa berikut ditampilkan tabel dan grafik hasil belajar siswa pada kondisi awal, hasil Post test siklus I dan hasil post test pada siklus II.

Tabel 6. Data Nilai Hasil Belajar pada kondisi awal, siklus I dan siklus II

\begin{tabular}{|c|c|c|c|c|}
\hline \multirow[b]{2}{*}{ No } & \multirow[b]{2}{*}{ Nawa Siswa } & \multicolumn{3}{|c|}{ Nilai dan Keriteria } \\
\hline & & $\begin{array}{c}\text { Kondisi } \\
\text { Awal }\end{array}$ & Siklus 1 & Siklus 2 \\
\hline 1 & Ahmad Fadillah & 70 & 70 & 63 \\
\hline 2 & Ahmad Nabawi & 80 & 80 & 100 \\
\hline 3 & M. Rizqi Ramadhan & 80 & 80 & 100 \\
\hline 4 & Muhammad & 70 & 70 & 75 \\
\hline 5 & Muhammad Nur Rafly & 80 & 90 & 100 \\
\hline 6 & Nor Aini & 60 & 60 & 63 \\
\hline 7 & Nur Fayza & 70 & 70 & 88 \\
\hline 8 & Riski Amalia & 80 & 80 & 88 \\
\hline 9 & Rizkia Halwa & 70 & 70 & 75 \\
\hline 10 & Rodhiah & 80 & 80 & 88 \\
\hline 11 & Selvina & 80 & 90 & 88 \\
\hline 12 & Siti Halimatus Sa'diyah & 80 & 80 & 100 \\
\hline 13 & Tiara Ayu Anindia Putri & 70 & 80 & 75 \\
\hline 14 & Wardatul Fitria & 70 & 80 & 75 \\
\hline 15 & Zahratul Ain & 70 & 80 & 88 \\
\hline 16 & Zupiru Camaliya & 60 & 70 & 63 \\
\hline & Jumlah & 1170 & 1230 & 1329 \\
\hline & Rata-rata & 73,13 & 76,88 & 83,06 \\
\hline & Nilai Tertinggi & 80 & 90 & 100 \\
\hline & Nilai Terendah & 60 & 60 & 63 \\
\hline
\end{tabular}

Penelitian hasil belajar siswa dapat dilihat berdasarkan siklus 2, dengan melihat pada tabel dibawah ini:

Tabel 7. rata-rata nilai awal dan nilai siklus 2

\begin{tabular}{clccc}
\hline \multirow{2}{*}{ No } & Komponen Analisis & \multicolumn{3}{c}{ Nilai rata-rata } \\
\cline { 3 - 5 } 1. & Jumlah & 1170 & 1230 & Siklus 2 \\
2. & Rata-Rata & 73,13 & 76,88 & 1329 \\
3. & Nilai Tertinggi & 80 & 90 & 100 \\
4. & Nilai Terendah & 60 & 60 & 63 \\
5. & Jumlah Tuntas & 7 & 10 & 13 \\
6. & Jumlah Tidak Tuntas & 9 & 6 & 3 \\
7. & Tingkat Ketuntasan & $43,75 \%$ & $62,5 \%$ & 81,25 \\
\hline
\end{tabular}


Sebagai gambaran yang jelas mengenai perbandingan antara persentase ketercapaian hasil belajar siswa di awal proses pembelajaran, akhir siklus I dan akhir siklus II, dapat dilihat pada grafik berikut:

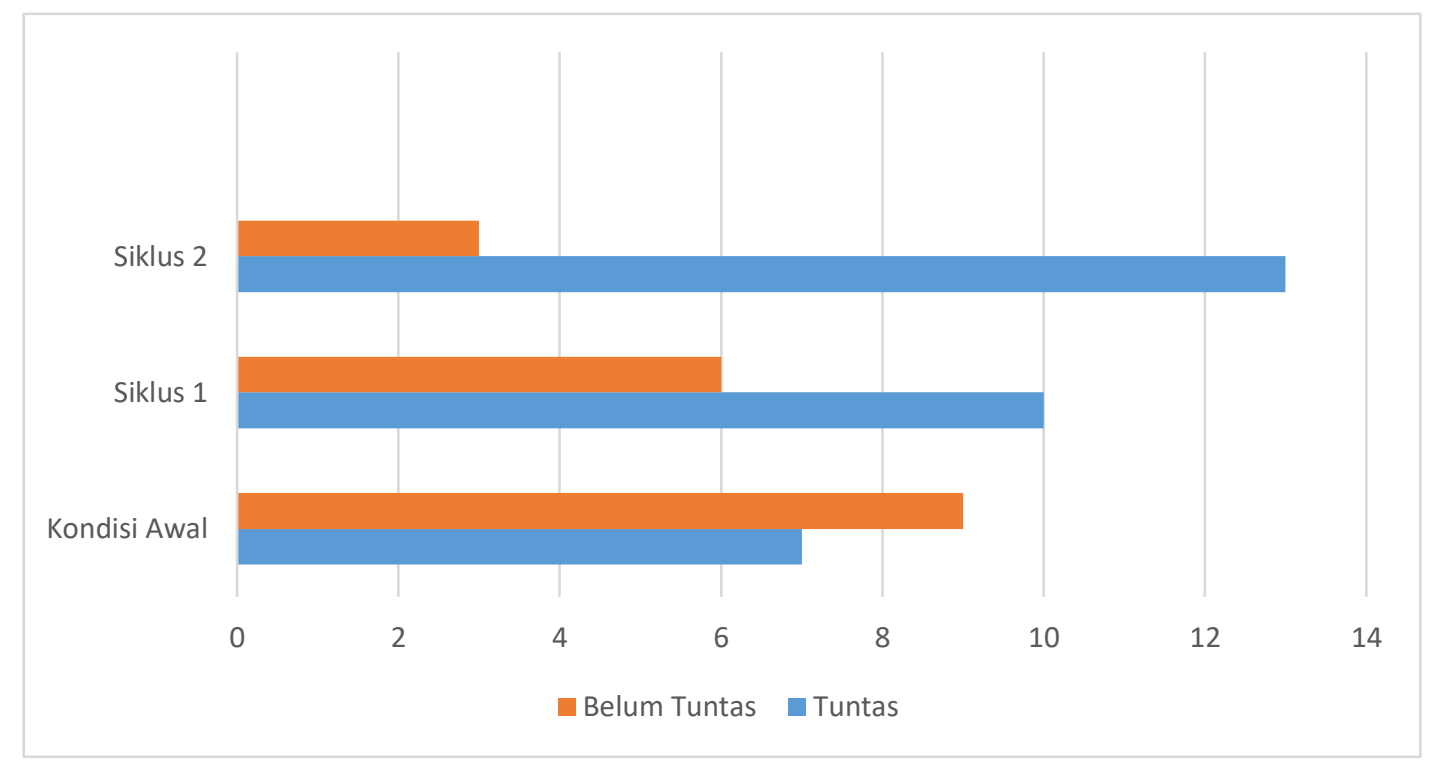

Gambar 6. Visualisasi Hasil belajar (Post Test) pada Kondisi awal siklus I, dan siklus II

Berdasarkan grafik di atas dapat disimpulkan bahwa Hasil Belajar siswa mengalami peningkatan dari kondisi awal yang mencapai KKM hanya 7 orang atau 43,75\% meningkat menjadi 10 orang atau $62,5 \%$ pada siklus I dan menjadi 13 orang atau $81,25 \%$ pada siklus II.

\section{KESIMPULAN}

Hasil penelitian Tindakan kelas yang sudah dilakukan oleh penulis dapat di simpulkan bahwa: Penerapan Model Pembelajaran Kooperatif Make A Match Materi Mengenal Allah swt Melalui Asmaul Husna dapat meningkatkan Hasil Belajar Siswa Kelas 5A MI Hidayatullah Martapura Semester 1 Tahun Pelajaran 2021/2022 dengan tingkat ketuntasan pada siklus I sebanyak $62,5 \%$ dan siklus II sebanyak $81,25 \%$. Adapun peningkatan ketuntasan dari siklus I dan Siklus II sebesar 18, $75 \%$. Peningkatan tersebut terjadi karena dalam metode make a match memiliki karakteristik seperti kerjasama, permainan, dan penghargaan (hadiah) sehingga siswa dapat bekerja sama dalam memecahkan masalah serta tercipta suasana belajar yang menyenangkan, asyik, dan aktif.

\section{DAFTAR PUSTAKA}

Ahmad, Suriansyah., dkk. (2008). Pedoman Penulisan Karya Ilmiah (Skripsi) Khusus untuk Penelitian Tindakan Kelas, Banjarmasin; UnIIersitas Lambung Mangkurat FKIP.

Aris Shoimin. (2014), 68 Model pembelajaran Inovatif dalam Kurikulum 2013, Jakarta, Ar Ruzz Media.

Arikunto, Suharsimi., dkk. (2008). Penelitian Tindakan Kelas. Jakarta: Bumi Aksara.

Astika, N. (2012). Efektivitas Model Pembelajaran Kooperatif Tipe Make A-Match Terhadap Hasil Belajar Siswa. Jurnal Penelitian Pembelajaran Fisika, 3(2).

Delila M. (2017). Upaya meningkatkan hasil belajar siswa kelas ii sdn haus melalui penggunaan model pembelajaran kooperatif tipe make a match pada materi empati dan simpati. Langsat Jurnal Ilmiah Pendidikan Dan Sosial, 4(2), 1-8.

Hairiah. (2021). Model Pembelajaran Pada Masa Covid-19 di Indonesia. Journal of Instructional and

Development

Researches,

$1(1)$,

$1-9$. 
Penerapan Model Pembelajaran Kooperatif Make a Match Sebagai Upaya Meningkatkan Hasil Belajar Aqidah Akhlak Materi Asmaul Husna Kelas V

https://doi.org/https://doi.org/10.53621/jider.v1i1.15

Prihatiningsih, E., \& Setyanigtyas, E. W. (2018). Pengaruh Penerapan Model Pembelajaran Picture and Picture Dan Model Make a Match Terhadap Hasil Belajar Siswa. Jurnal Pendidikan Sekolah Dasar, 4(1), 1. https://doi.org/10.30870/jpsd.v4i1.1441

Saenab, S., Yunus, S. R., \& Virninda, A. N. (2017). PjBL untuk Pengembangan Keterampilan Mahasiswa: Sebuah Kajian Deskriptif Tentang Peran PjBL dalam Melejitkan Keterampilan Komunikasi dan Kolaborasi Mahasiswa. Seminar Nasional Lembaga Penelitian UNM, 2(1), 45-50.

Safaruddin, Degeng, I. N. S., Setyosari, P., \& Murtadho, N. (2020). The effect of PJBL with WBL media and cognitive style on students' understanding and science-integrated concept application. Jurnal Pendidikan IPA Indonesia, 9(3). https://doi.org/10.15294/jpii.v9i3.24628

Safaruddin, S., Ibrahim, N., Juhaeni, J., Harmilawati, H., \& Qadrianti, L. (2020). The Effect of Project-Based Learning Assisted by Electronic Media on Learning Motivation and Science Process Skills. Journal of Innovation in Educational and Cultural Research, 1(1), 22-29. https://doi.org/10.46843/jiecr.v1i1.5

Sai, M. (2017). Pengaruh model group investigation berbasis internet terhadap hasil belajar dan kemampuan digital literasi siswa. Harmoni Sosial: Jurnal Pendidikan IPS, 4(1), 39. https://doi.org/10.21831/hsjpi.v4i1.9869

Salehudin, M. (2020). Project-Based Learning Berbantuan E-Learning: Pengaruhnya Terhadap Hasil Belajar. Tadrib: Jurnal Pendidikan Agama Islam, 6(1), 28-40.

Sugiarti, R., \& Pribadi, A. S. (2013). Analisis faktor yang mempengaruhi keberhasilan belajar siswa slow learner di Sekolah Luar Biasa (SLB) Negeri Semarang. Journal Wacana, 5(1), $1-17$.

Sugiono. (2016). Metode Penelitan Kuantitatif, kualitatif dan R\&D. Bandung: Alfabeta.

Wahyono, P., Husamah, H., \& Budi, A. S. (2020). Guru profesional di masa pandemi COVID-19: Review implementasi, tantangan, dan solusi pembelajaran daring. Jurnal Pendidikan Profesi Guru, 1(1), 51-65. http://ejournal.umm.ac.id/index.php/jppg/article/view/12462

Wijanarko, Y. (2017). Model Pembelajaran Make a Match Untuk Pembelajaran Ipa Yang Menyenangkan. Taman Cendekia: Jurnal Pendidikan Ke-SD-An, 1(1), 52. https://doi.org/10.30738/tc.v1i1.1579 